\title{
Analysis on the Application of Maker Education in the Cultivation of Educational Technology Major
}

\author{
Qian Yan ${ }^{1, a}$ \\ ${ }^{1}$ Baicheng Normal College, Media Institute, Baicheng, Jilin \\ aqianyan1982@126.com
}

Keywords: Maker Education; Educational Technology; Practice

\begin{abstract}
This paper discusses the concept of Maker Education, expounds the education theory in the application of Education Technology Major, from the content of the Information Technology and the education method, process and evaluation and explores the role transformation between teacher and student. Maker Education is a kind of innovation, practice, sharing of education activities, encouraging students to explore, invent and create the active participation, collaboration, learning, cultivate students' innovative consciousness, innovative thinking and innovative ability and team spirit. Gen guest teaching on the basis of information technology, integration innovation education, experience education, DIY concept, project learning, etc. As one of the new education pattern, is in comprehensive curriculum implementation of technical curriculum as the core of a beneficial attempt and the continuous improvement of the teaching method as a guest, and constantly optimized, to improve students' communication ability, cooperation ability, reflection ability, problem solving ability, and play a certain role in the development of innovation ability, can become the breach of the school education to carry out the Maker Education, the characteristics of the development of the new luminescent spot can also be used as a school.
\end{abstract}

\section{Introduction}

With 3D printing technology, the development of open source hardware and other high and new science and technology, the global trigger a flood of introducing Maker Education. Maker Education would lead a new round of innovation talents training. Abroad: the development of the United States in recent years in universities introduce "the maker room", equipped with hardware and software facilities, 3D printers and all kinds of high-tech equipment. Maker Education will be training the new idea of education and technical personnel, the maker room is the education of colleges and universities and technical personnel gathering place of the communication. Maker Education in today's world has become a important way of training innovative talents. therefore, to create customer education and Education Technology talent training model of combining exploration is to pay attention to. But, at present has not been put into practice, just on the theoretical research.

Maker Education is the most recent three years the rise of a kind of education idea. Maker Education combined with Education Technology undergraduate course personnel training mode there is almost no research literature, there are only individual journal articles. These articles mainly expounds some views in theoretical sense, put into practice of literature is a handful. Due to the maker movement first arose in the United States, is the study of a passenger platform at first, and then into a maker education to promote research of talent training. Therefore, the research to our country and abroad customer education and Education Technology undergraduate talents training model of combining the study provides reference.

Maker Education in China is rising in the recent two or three years. For the education and Education Technology undergraduate talents training is only a theoretical research. Through the understanding of problems of Education Technology undergraduates in our country and the education idea, the maker and Maker Education based Education Technology undergraduate course personnel training mode research, should according to the specific situation of Chinese colleges and universities. To learn the essence, eliminate dregs. In view of the problems, analysis of education 
technology in the undergraduate course personnel training to carry out the education factor. The last build model suitable to China's development of Education Technology undergraduates.

At present, the education is to promote the development of innovative talents. It takes a potentially explosive impact the campus learning. But Maker Education course personnel training and Education Technology research to stay on the surface level. Therefore, we must find the connection between Education Technology and Maker Education, build accord with practical personnel training mode in our country, the feasibility to prepare for the future theory into practice.

\section{The Idea of Maker Education}

Maker Education provides learners with a new education idea, its theoretical basis based on" learning by doing" , " happy education", "innovation education".

A. The Idea of "Learning by Doing"

The real purpose of "learning by doing" is to let students experience from the real social situation, Learning is not only reflected in the classroom, it is particularly important to continue to learn in practice. Only in the process of "doing", students can find the shortcomings and play the wisdom to solve the problem.

B. The Idea of "Happy Education"

A maker, for the purpose of education to cultivate comprehensive talents with creative spirit stimulate students interest, it gives students more freedom of choice, and will create interest, aesthetic, understand to dissolve into education. Students can choose a topic of interest, selection of equipment, oneself start work make, enjoy each harvest to own happiness. And the interference of learners do not have any effect, I'd like to, I'd be happy to, I will create.

C. The Idea of "Innovative Education"

In today's society, national prosperity depends on education, and education depend on innovation. Therefore, a core education lies in the innovation education, innovation education is interest, motivation, enthusiasm and creative combination, it can stimulate the creativity of the students, and create Maker Education advocates each students to give full play to the subjectivity, initiative, be good at discovery learning, life, create will use new problems and difficulties in the work. Its aim is to cultivate courage to explore, dare to innovation of new talents in the 21st century.

\section{The Value of Innovation}

According to the national development trend, the future students will be from the pure knowledge of consumers into creators, in this conversion, the creation of education is playing an important role. Although the foster education has just entered the Chinese education land, but in recent years the development trend of view, foster education will promote innovation in the 21st century talent training. The potential value of education is huge, and it will play an important role for individuals, schools and countries.

\section{A. Individual Development level}

Foster education to do secondary school, innovative education, happy education and other ideas for the organic whole. To meet the students full of curiosity and creativity of nature. It combines the language, mathematics, art and other disciplines, to cultivate students' innovative spirit and ability to solve practical problems. In the space of the passenger, the minds of the minds of the collision, mutual communication, mutual help, but also rub the wisdom of the spark. In addition, students in the exploration also strengthened the understanding of abstract knowledge.

\section{B. School development level}

The examination-oriented education adopts the mechanized education way to train the students. It measures the comprehensive quality of the students with the test scores, evaluates the quality of the school education by the level of the study rate, strangling the students' imagination and the spirit of innovation. Foster education is to subvert the traditional school teaching concept, for the school development into a life. Through the provision of students to explore, project learning and hands-on operation based on the creation of learning methods for students to provide a good campus 
environment. In addition, the school should mobilize all the positive factors of the country to participate in school education, work together to create a ubiquitous space for the creation of a balanced development of the school education system for future students out of school life to do a series of preparation.

\section{National development level}

With the 3D printing technology, network information, micro controllers and other open source hardware platform is becoming increasingly mature, innovative talents become the strategic focus of national training. Our country is promoting the development of innovative learning society. Education and the maker and the maker space collision and the exchange, has solved the problems of lack of innovative talents, the main cultivation have the courage to explore, innovation of practical talents, to prepare for the country's long-term development.

\section{Factors Influencing the Implementation of Maker Education in the Cultivation of Educational Technology}

In a movement under the background of worldwide, as a new concept, Maker Education advocates the cultivation, It has innovation consciousness and practical spirit and the makers only. In view of this, Education Technology in the undergraduate course personnel training to carry out Maker Education need to consider the following three factors:

\section{A. Maker Room}

After the introduction of the maker room in campus, a campus and maker room. Campus space will be makers to Education Technology undergraduate course personnel training to bring the following benefits:

The maker room is a maker gathered fans to share communication space. In traditional Education Technology learning environment, students exchange scope only limited to the same school and professional, interdisciplinary communication is rare. Therefore, Education Technology undergraduates only mastered the basic computer knowledge and basic skills, don't know anything about related disciplines outside of Education Technology professional knowledge, students knowledge narrow, schools and the maker room can effectively promote interdisciplinary communication of education technology undergraduates.

The maker room can be multimedia classroom to form good complementary. Multimedia classroom environment exist fixed time, and do not like the maker as open space. And in general is given priority to with teacher, professor, single study way, more is given priority to with academic discussion. And schools and the maker room is not representative resources and space itself, it advocates are happy learning, depth of experience, the concept of collaborative innovation, is the knowledge and practice, the combination of the interest and create. Students can do the thing that oneself like, also can participate in discussions and participate in the creation, its aim is to cultivate students' innovative practice ability, also provided a basis for business in the future employment.

There are more learning facilities in maker room. Education Technology under the environment of the equipment in general is given priority to with multimedia classroom. Campus in the maker room is given priority to with practice and innovation. Have a 3D printer, desktop devices, mobile terminals, comprehensive coverage of high-speed wireless network, and open source hardware, etc. Education Technology is a discipline of integrating theory with practice. The students master the tools, the surface of employment after graduation will be more widely, in addition to the primary school information technology teachers, can also into software companies, etc.

\section{B. Curriculum Structure}

Developing curriculum structure is only one way to solve the malpractice of traditional courses effectively.

Integration of the maker content and multidisciplinary. In traditional Education Technology learning environment, students mainly focusing on the discipline knowledge, other disciplines content is poorly understood. this professional level can not meet the information age of the students' knowledge. On this basis, the curriculum to comprehensive consideration. In addition to 
courses in Education Technology related, should also be involved in education, literature, art, mathematics, physics or related discipline knowledge. In-depth analysis on the education content, actively explore the discipline integration, using Information Technology to solve the problem of discipline, discipline knowledge support and education development. The purpose is to promote the optimization and upgrading of subject knowledge and information fusion technology.

Establish intercollegiate elective system. Education Technology talents by each school's website, cross school elective. At present, the colleges and universities should establish MOOC platform for universities listen to each other. Education Technology is a cross discipline, students must grasp the subject knowledge to support the research and practice.

C. The Teachers troop

Maker Education in the education is picking up in China, driving the development of innovation education in China. Practice and innovation ability of undergraduate talent Education Technology is the value orientation of Maker Education. University education and technical personnel to develop maker, must establish the teachers troop, meet the demand of Education Technology talented person development in our country.

The spirit of innovation. Innovation is the future must possess the spirit of the characteristics of teacher culture in our country. Compared with traditional Education Technology teachers, and the modern teacher is not satisfied with their current knowledge structure, they are looking for new knowledge, exploring the mystery of the world in the future. Secondly, the modern teacher is strongly seeking for knowledge, whether at work or new problems or new things in life, they will use to create talents to solve it.

Extensive knowledge. As a good teacher, Education Technology basic theory knowledge and skills are completely unable to adapt to the era of guest to teacher's professional demands, a qualified teachers should have diversified knowledge structure, to the Chinese, math, physics, art and other disciplines should be to understand, but also to the latest development of this professional give high attention.

With the basic theoretical knowledge and skills of Educational Technology is completely unable to adapt to the era of teacher professional demand, a qualified teacher to have a diversified knowledge structure. Disciplines should be understood, but also on the professional development of the latest developments to give high attention.

With the practical ability. The makers are a group of courageous enough to seek stimulation, to combat type personnel of innovation. The maker is in the depth of experience their own creative process. As modern teacher, college teachers should not only have good ideas, but also the ability to play to achieve it. Thus, modern teachers must master program design, 3D printing can develop corresponding software and hardware facilities.

With innovative ability of teaching. Traditional Education Technology environment, the classroom is the place that teachers play, therefore, causes the student to study way drab and boring. In a customer environment, the teacher must be good at using new technology to the student teaching (such as: network technology, multimedia technology, etc.). Second, lead the students into the micro-standard classroom, teaching way transformation, play a guiding role. Finally, to be able to introduce their own innovation class, with their own creativity to inspire students' enthusiasm to professional.

\section{Build a Model based on "learning environment"}

In the Education Technology undergraduate talent training, make full use of the platform for entrepreneurship education, encourage students to participate in creative activities, and strive to transform the results into results. This kind of creative activities make up for the shortcomings of ignoring the interest and practical ability in the Educational Technology environment and change the traditional teaching methods. Based on the "model of learning environment", the educational model is based on the "campus space" as the carrier, "the passenger course" and "the teacher" as the condition, the purpose is to develop the Educational Technology students thinking, Technical ability. This kind of education mode is the problem-oriented, from the interest of students to stimulate the 
starting point, aimed at out of the traditional Educational Technology environment, students innovative ability to practice poor, single learning and other defects. The author from the classroom and extracurricular aspects of a specific analysis.

Classroom level: Based on the traditional educational technology background, the teaching model is "teacher-oriented", students access to professional knowledge is mainly through the teacher to explain, and teachers and students can not choose each other, with a certain degree of fixed. In the Education Technology professional skills training, due to the lack of multimedia classrooms, each student on the machine operation has time constraints. In the "learning environment", a group of innovative teachers is a group of innovative people, their teaching method is not a simple knowledge to explain, but step by step to guide students to master the basic knowledge and basic skills under the premise of training students Thinking and practical ability. Students can also obtain professional knowledge through MOOC, micro course and so on. Secondly, the teachers and students to develop their own characteristics of the curriculum and promote the Education Technology undergraduate students can learn from the works of teachers to develop their own creative works, so that students get inspiration, but also to avoid detours, After completing the student's work, the teacher will improve his teaching method. Finally, Educational Technology itself is a very practical course, students must master the latest software tools. "Pioneer learning environment" for the Educational Technology to provide the latest hardware and software facilities, students can at any time practical practice, improve practical ability.

Extracurricular level: based on the traditional Educational Technology background, students access to knowledge is mainly through the classroom to explain, practice the practice of classroom-based training, resulting in Educational Technology students learning a single way, knowledge access narrow, lack of courage to explore innovative quality of practice , In the "learning environment", the campus space is the Educational Technology students to display the space platform. First, the maker space open 24 hours a day, it has a certain hardware and software facilities platform. Educational practice within the classroom does not meet the needs of students, students to learn technical knowledge, you can use the maker space, practice exercises in the extracurricular. Second, the maker space is the interest of enthusiasts to display their talent space, not only educational technology, but also a variety of disciplines. Education technology on the basis of learning the knowledge of the subject, you can understand the knowledge of other disciplines, and promote the optimization and reorganization of Information Technology and subject knowledge. For example, when doing large works, a good creative work, not only need a solid practical skills, but also to understand the education, literature, art, mathematics, physics and other related disciplines. Finally, the maker space will be linked from different schools, different professional entrepreneurs to the customer education platform through the Internet community, Educational Technology students can share their creative intentions, through collaborative exchanges, and constantly improve their own development.

\section{Conclusion}

The development of Maker Education, to the Educational Technology undergraduate talent to bring plasticity. "learning by doing ", "happy education", "innovative education" and so on, to cultivate innovative thinking, practical ability, collaboration and exchange of innovative Educational Technology talent to add vitality.

However, due to the infection of the examination-oriented education, China's Education Technology undergraduate talent training faces a variety of problems: poor innovation and practical ability to lead to the lack of innovation and combat talent in China; low social needs, a sing the employment pressure; To teach as a teacher to obtain an important source of knowledge, resulting in a single learning style .learning range is small, resulting in Information Technology and curriculum integration and other issues weak. All the above difficulties will hinder the development of Educational Technology undergraduate talent development prospects.

In the face of various problems in the cultivation of undergraduate education in Education Technology, we must actively explore an educational model that combines the Maker Education 
with the undergraduate talents of Educational Technology. Through the understanding of the Maker Education, it is concluded that the biggest difference between the Maker Education and the Education Technology is that the educational environment is not the same. Therefore, the implementation of Maker Education to the Education Technology undergraduate talent training needs three elements, namely, campus space, maker courses system, makers team. Based on the above analysis, so as to build a "learning environment" education model. How to apply the "learning environment" education model to the undergraduate training of Educational Technology, the author elaborated from the two levels of classroom and extracurricular.

In short, the innovative talents are the primary consideration for the state to nurture talent. China's Educational Technology talent will shift from the test environment to a Maker-style learning environment, but our country is currently only at the theoretical level of research, did not break through the practical level. Therefore, we must first explore a feasibility of personnel training model to guide the practice of theory. Based on the "learning environment" of the educational model to build, to a certain extent, will alleviate the Education Technology undergraduate talent cultivation of many problems for our country to cultivate innovative practice, innovation and employment and information technology and subject knowledge of the new Education and technical personnel are ready. Therefore, we have to seize the opportunity to create opportunities for education and technical personnel to cultivate icing on the cake.

\section{Acknowledgments}

This work was supported by the "Research on the Problems and Countermeasures of Community Education Information Management in Western Jilin" (Jilin Provincial Department of Education, No. 14, 2016) in part. The author would also like to thank the reviewers for their corrections and helpful suggestion.

This work was supported by the Research on "A Study on the Construction and Application of MOOC - Taking Baicheng Normal College as an Example (Jilin Province Education Reform Project, October 2015 to December 2017) in part also. The author would also like to thank the reviewers for their corrections and helpful suggestion.

\section{References}

[1] Yang Li. Maker Education and Classroom Innovation [J]. Education Technology in Primary and Secondary Schools, 2015 (06);

[2] Fu Zhiyong. The Creative Space and Ecological Construction of Maker Education [J]. Modern Educational Technology,2015(05);

[3] Wu Weiyu. The Present Situation and Enlightenment of Domestic and Foreign Research on Maker Education [J]. Asia and Pacific Education,2015(35);

[4] Zhu Zhiting. From Maker Movement to Create Education: Cultivating the Culture [J]. Research on Education Technology, 2015(07);

[5] Yang Xianmin, Li Jihong. The Potential of the Value of Maker Education and Its Disputes [J]. Modern Distance Education Research,2015(02);

[6] Zhen Yanlin.An Analysis of the Path of Implementing Customer Education in American Universities[J]. Open Education Research,2015(06). 